GEOLOGICAL SURVEY CIRCULAR 522

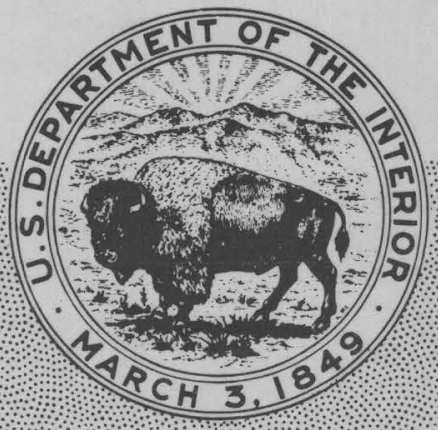

Resources of Oil, Gas, and Natural-Gas Liquids in the United States and the World 



\title{
Resources of Oil, Gas, and Natural-Gas Liquids in the United States and the World
}

\author{
By T. A. Hendricks
}

x

Geological Survey Circular 522 
United States Department of the Interior STEWART L. UDALL, Secretary

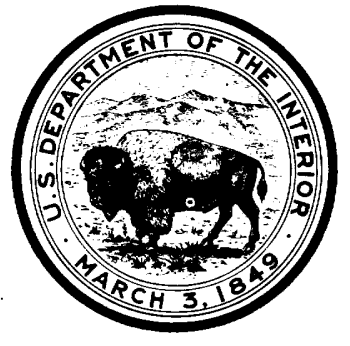

Geological Survey

William T. Pecora, Director

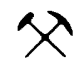

REPRINTED

1966

Free on application to the U.S. Geological Survey, Washington, D.C. 20242 


\section{CONTENTS}

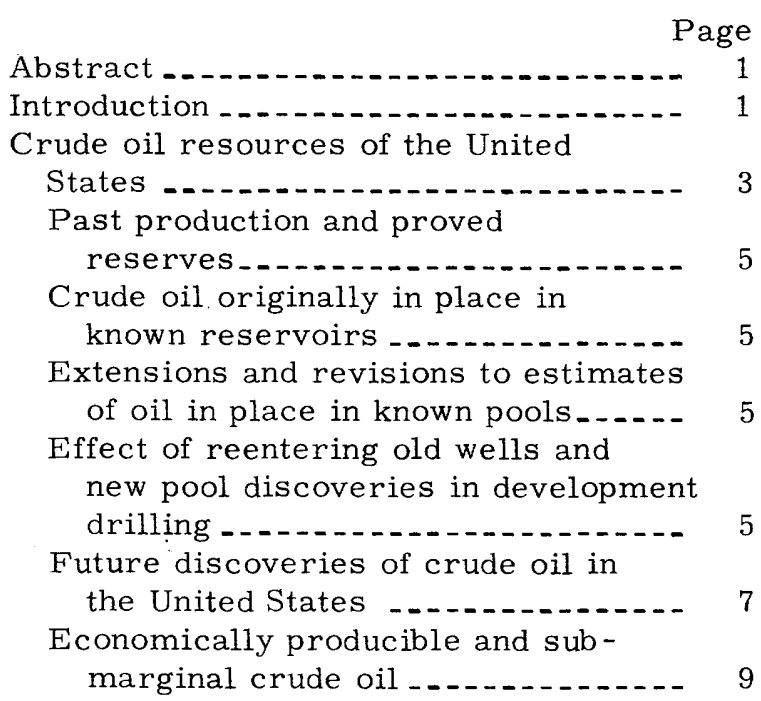

ILLUSTRATIONS
United States resources of natural gas and natural-gas liquids _...-..Summary of United States resources of crude oil, natural gas, and

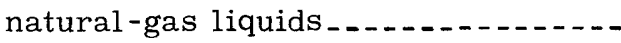

Potential world resources of oil, gas, and natural-gas liquids _.......... Comparison of the relatively highly explored areas of the United States with the remainder of the world .. Relative productivity of various areas in the United States ..Application of factors derived for the United States to the remainder of the world ....-

Conclusion _. .

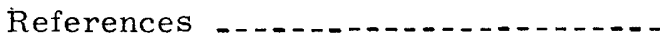

Page

10

Figure 1. Diagram illustrating conceptual components of total oil in the ground.........

Page 2-4. Graph showing-

2. Effect of crediting extensions and revisions back to year discovery........

3. Production and proved reserves of crude oil and its equivalent by States and the grouping of States in categories of productiveness

4. Cumulative totals of past production plus proved reserves as compared with cumulative total of exploratory footage drilled ......

\section{TABLES}

Table 1. New fields and new pools discovered without additional exploratory drilling ....

2. Cumulative totals of past production, proved reserves, and exploratory

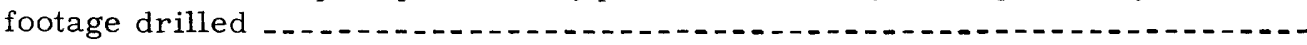

3. Oil, gas, and natural-gas liquids originally underlying the United States .......

4. Production and proved reserves of crude oil, natural gas equivalent, and natural-gas liquids by States as of January 1, $1962 \ldots \ldots$

5. Amount of oil, natural gas, and natural-gas liquids in areas of various degrees of potential in the United States

6. Estimated quantities of petroleum and natural gas originally in place in world areas and bordering continental shelves

7. World oil resources by regions .... 



\title{
Resources of Oil, Gas, and Natural-Gas Liquids in the United States and the World
}

\author{
By T. A. Hendricks
}

ABSTRACT

The amount of crude oil originally in place in the world is estimated at slightly less than 10,000 billion barrels, of which approximately 1,600 billion barrels was in the United States. Natural gas originally in place in the world $\mathrm{i} r$. estimated at more than 30,000 trillion cubic feet, of which about 4,000 trillion cubic feet was in the United States. Liquids originally contained in the natural gas of the world are estimated at more than 800 billion barrels, of which about 120 billion barrels was in the United States.

It is estimated that in the United States about five-eighths of the oil and gas originally in place may be discovered. Also, it is estimated that one-fourth of the oil originally in place and one-half of the gas and associated liquids may be produced ultimately. Because of the great differences in economic and physical settings, no such breakdown is attempted for the world as a whole.

The first step was to estimate the quantities of oil gas, and natural-gas liquids originally in place in the United States. This is done more easily for the United States than for most other areas of the world because data are more abundant and more accurate. This estimate was based on available data on exploratory footage drilled, fraction of the total volume of sedimentary rocks explored, past production records, estimates of proved reserves, and the attractiveness of the explored rocks relative to that of the rociss as yet unexplored. The next step was to divide productive areas of the United States into four categories according to relative productivity. A factor of the quantity in place per thousand square miles was derived for each commodity in areas of each category. Final steps were to divide the sedimentary areas of the world into categories similar to those of the United States, to multiply the measured area of each category by the appropriate factor, and to add together the resulting quantities for areas of regional or continentwide extent.

\section{INTRODUCTION}

This study of the resources of petroleum, natural gas, and natural-gas liquids of the United States and the world was originally undertaken jointly by A. D. Zapp (deceased), J. F. Pepper (deceased), and T. A. Hendricks. Zapp prepared most of the part dealing with resources in the United States. Much of Zapp's methodology follows that used in 1962 in estimating the future petroleum producing capacity of the United States (Zapp, 1962). Pepper and Hendricks each classified the sedimentary basins of the world geologically according to their relative potential. They then resolved their differences in evaluation by specific discussion. Pepper computed the area of each basin unit outside the United States. Hendricks developed the procedure used and computed the quantities of crude oil, natural gas, and natural-gas liquids for the areas of the world as classified by Pepper and Hendricks. He also consolidated the material and wrote the final report. Credit for their ideas and methods should go to Zapp and Pepper. Responsibility for the complete report rests with the author.

The problems of estimating oil and gas potential are markedly different from those of estimating other fossil fuels. Coal, oil shale, and asphalt occur in solid bodies that are extensively exposed at the earth's surface, where their dimensions, character, and geologic relations may be observed directly. Oil and gas accumulations, by contrast, are not exposed; moreover, they occur as fluids filling fractures and intergranular spaces in the rock in a much wider range of stratigraphic settings than the solid fuels. In short, resources of the solid fossil fuels are at least partially visible and relatively concentrated, whereas resources of oil and gas are entirely unseen and relatively diffuse.

Because man cannot see oil and gas resources, it is not surprising that he has been ultraconservative in estimating yet-undiscovered quantities. Repeatedly, expert estimates of total undiscovered quantities have been exceeded within a decade or so by quantities actually discovered. This conservatism regarding the unseen is also reflected in estimates of yet-to-be-produced quantities in accumulations that have already 
been outlined by drilling, that is, estimates of "proved reserves." The record shows that estimates of ultimate recovery from drilled pools are generally revised sharply upward as cumulative production mounts.

Geological science has been very successful in classifying parts of the earth's crust as favorable, unfavorable, or impossible for the occurrence of oil and gas, but the exact location and extent of the occurrences can be determined only by drilling. By the same token, only extensive drilling and production experience can provide the statistical sample needed to attempt quantitative estimates of the producible quantities in the unexplored favorable parts of the earth's crust. Moreover, much of the purely geologic information needed for intelligent appraisal of unexplored rock can be provided only by drilling.

At present, only a tiny part of the geologically favorable rock in the earth's crust has been explored by drilling. The amount of exploratory footage drilled in the United States dwarfs the total footage in the rest of the world, but even in the United States there is "room" in the geologically favorable rocks for more than six times as much exploratory drilling as has been done so far. Until a far larger "sample" has been drilled, estimates of undiscovered quantities will be subject to major revision.

In this report an attempt is made to estimate the potential resources of the United States by utilizing the statistical results of drilling and to estimate the potential of other parts of the world by comparing their geologic characteristics with the United States.

Consideration is limited to the continents, the continental shelves, and island areas. Oil, gas, and associated liquids may be present beneath the continental slopes and oceanic basins, but no information exists on which to base estimates. Also, consideration is focused on these quantities originally in place in the rocks and on the amounts that may reasonably be expected to be discovered by exploration and development. Far larger quantities of hydrocarbons than those here considered are present in disseminated form in the rocks and fluids of the earth's crust. For example, Buckley, Hocott, and Taggart (1958, p. 882) have shown that the quantity of hydrocarbon gas dissolved in the subsurface waters beneath the Gulf Coastal Plain probably exceeds the producible gas known in that province at the time of their study. Similarly, it is well known that virtually all coal deposits contain appreciable quantities of natural gas, but only rarely have they served as commercial gas reservoirs. Lasky and others (1962) discussed this subject and concluded that the potentially usable methane contained in the coal beds of the United States might be $350-400$ trillion cubic feet. The Oil and Gas Journal (Apr. 20, 1959, v. 57, no. 17, p. 82; and Mar. 12, 1962, v. 60, no. 11, p. 83) reported that more than 2 trillion cubic feet of methane is dissolved in the water below a depth of 1,000 feet in the 526 square miles of Lake Kivu in Ruanda in central Africa.

Many estimates of ultimate crude oil resources have been made by well-informed students of the subject. The amounts estimated have ranged widely. Hubbert (1962) cited 14 estimates made by 12 individuals or groups between 1948 and 1962 . These range from 110 billion to 590 billion barrels. However, no two of the estimates were made on exactly the same basis, and much of the difference between them may be more apparent than real. For example, three of the estimates made by L. G. Weeks, a widely recognized student of the subject, are 110 billion barrels (Weeks, 1948), 204 billion barrels (Weeks, 1958), and 391 billion barrels (Weeks, 1959 , table 1). However, the 1948 estimate of 110 billion was restricted to resources recoverable by conventional primary methods in terms of then current economics. The estimate of 204 billion made in 1958 included recoverable resources offshore that were not considered in 1948. The increase of Weeks' estimate to 391 billion in 1959 was largely due to the inclusion of 190 billion barrels producible by secondary recovery. The highest estimate by Weeks did not include Alaska.

Hubbert (1962, table 5) cited Zapp as having estimated in an unpublished report to the Natural Resources Subcommittee of the National Research Council "ultimate U.S. crudeoil reserves" at 590 billion barrels. Zapp's breakdown of that estimate, which was not cited by Hubbert, consisted of two parts: (1) ultimate resources (recoverable under) current economics and technology of 300 billion barrels and (2) submarginal ultimate resources of 290 billion barrels. Submarginal resources were defined in that unpublished report as being within two orders of magnitude of (currently) minable deposits in cost and quality. 
In that same report, and by statistical methods, Hubbert (1962, p. 72) estimated the total ultimate production of crude oil in the United States at 175 billion barrels. His estimate included production offshore and by improved recovery methods but did not include Alaska.

Moore (1962), in a thoughtful statistical analysis and projection of available data, concluded that the ultimate cumulative discoveries of crude oil in place in the United States will be 486 billion barrels of which 364 billion barrels will be recoverable. However, his estimates did not include Alaska and, because of the early stage of its development, the potential of offshore production probably entered into the projection to only a limited extent. The estimates probably do not make allowance for all discoveries of crude. Because of the lack of data on discoveries abandoned without any recorded production data, it is probable that no allowance is made for oil that may be producible from such deposits by techniques unknown at the time of discovery.

McKelvey and Duncan (1963), in a study conducted as part of a report of the Energy Policy Staff of the United States Department of the Interior, recast Zapp's estimates, supplemented by those of the Interstate Oil Compact Commission of oil recoverable by secondary methods already in practice, as follows:

$\begin{array}{lr} & \begin{array}{l}\text { Billion } \\ \text { barrels }\end{array} \\ \text { Known recoverable reserves....................... } & 48 \\ \text { Undiscovered recoverable resources.............. } & 200 \\ \text { Known marginal resources.......................... } & 40 \\ \text { Undiscovered marginal resources............... } & 300\end{array}$

These estimates total 588 billion barrels and do not include past production. The quantity of marginal resources that may be produced ultimately was not estimated.

Each of these estimates, as well as others, was made by a stated methodology, and most were made for a specific purpose. They are cited here in order to give the reader an idea of the variation in the amounts as estimated by knowledgeable scientists, some of the reasons for variation, and the general basis for some of the estimates.

\section{CRUDE OIL RESOURCES OF THE UNITED STATES}

The United States has been drilled for oil and gas far more intensively than any other large and geologically diversified area in the world. Consequently the results of this drilling should provide the most meaningful statistical sample for appraising possible ultimate potential. An estimate of the original total crude oil in the ground, for example, can be made by simple calculation if the following factors are known or can be estimated:

1. The quantity of crude oil found by exploration to date (1961).

2. The fraction of the potentially productive rocks that has been explored to date.

3. The estimated incidence of oil in the unexplored part of favorable rock as determined by comparison with the explored part.

As stated, the foregoing information is pertinent to estimation of oil in the groundnot to estimation of producible quantities. Estimation of what fraction of the total oil in the ground may ultimately be produced involves additional assumptions or estimates: (1) the future economic incentive to explore for and produce oil and (2) the extent to which progress in petroleum technology will increase the amount of oil that can be profitably recovered. Inability to predict the magnitude and effect of these factors introduces a weakness common to all estimates of ultimate discovery and production.

The statistical data from drilling in the United States are utilized to estimate the minimum total quantities originally underlying the United States and its adjoining continental shelves. As will be seen, none of the factors that enter into such a computation can be actually determined; many are purely matters of opinion. However, the analysis is given in such a manner that any reader who disagrees with any of the values assigned, or assumptions made, may substitute other values or other assumptions and derive his own estimates. 
A. Future revisions resulting from net increase in estimates of oil in place in dril.led acreage

B. Future extensions to known pools, through development drilling
C. In pools to be discovered in the course of development drilling of known pools

D. In originally subcommercial deposits and in drilled but undetected deposits that will be brought into production in the future

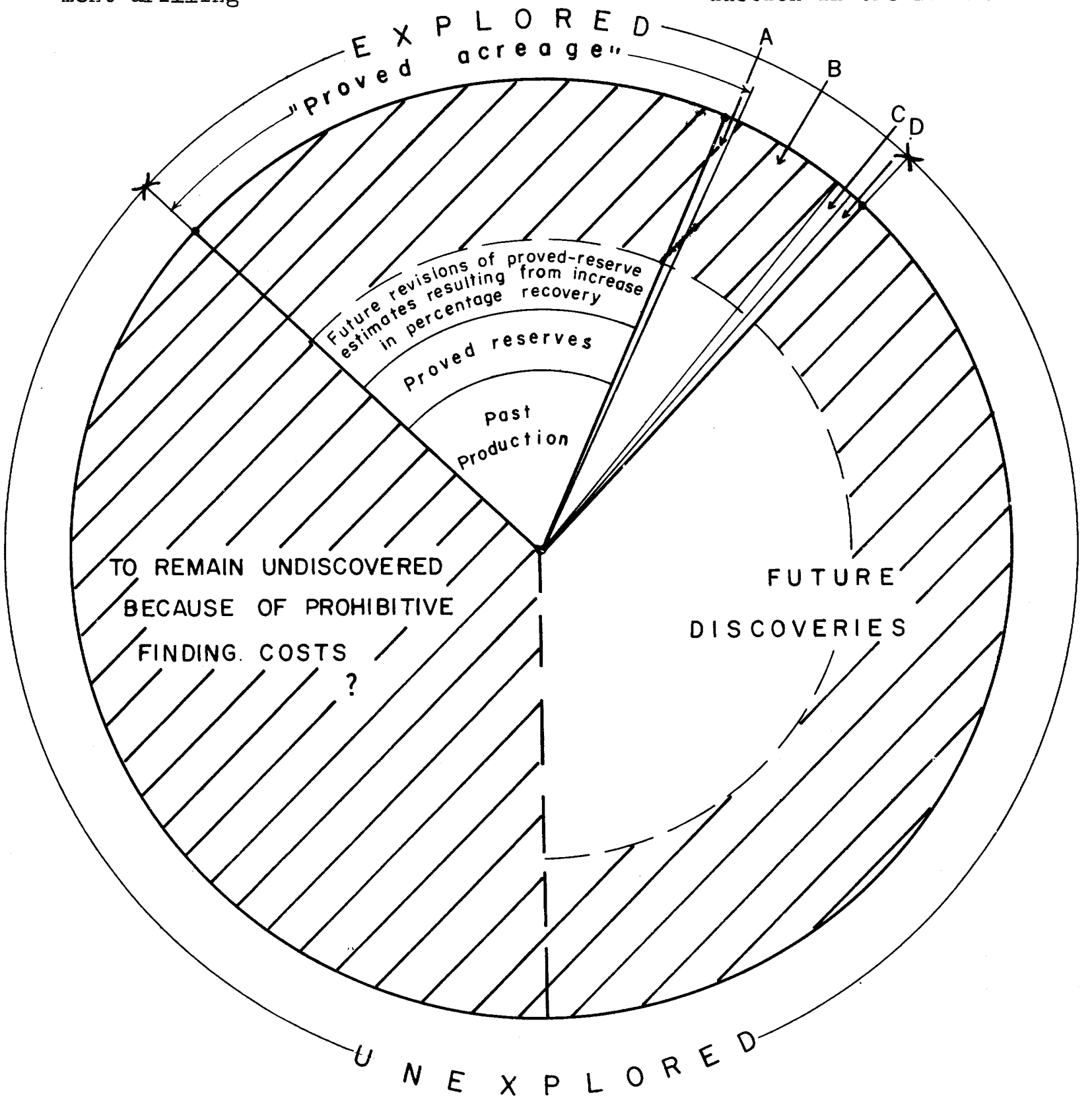

Economically recoverable

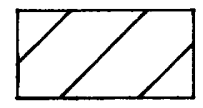

Submarginal

Figure 1. -Diagram illustrating conceptual components of total oil in the ground. Not drawn to scale. 
The order of magnitude of the total world amount of oil, gas, and natural-gas liquids originally in place is estimated by comparing the figures derived for various parts of the United States with those from areas considered geologically similar in other parts of the world.

The amount of crude oil in the ground consists of a number of increments which are summarized on figure 1. Only two of these quantities are known with relative accuracy, past production and proved reserves. The others can only be estimated.

\section{Past production an! PRoved RESERVES}

As of December 31, 1964, past production of crude oil in the United States totaled $75,231,533,000$ barrels. The American Petroleum Institute (1964) estimated the proved reserves of crude oil recoverable by methods already in operation in known pools to be $30,990,510,000$ barrels. The two quantities together total 106,222,043,000 barrels.

\section{CRUDE OIL ORIGINALLY IN PLACE IN KNOWN RESERVOIRS}

The Secondary Recovery Committee of the Interstate Oil Compact Commission estimated that, as of January 1, 1960, there was a total of 328.4 billion barrels of oil originally in place in known reservoirs (Torrey, 1960 , p. 42). This estimate includes most of the oil in the explored part of the favorable rocks but does not include all of the oil even for these areas. It does not include:

1. Future revisions resulting from net increase in estimates of oil in place in drilled acreage.

2. Future extensions to known pools through development drilling.

3. New pools to be discovered in the course of development drilling of known pools.

4. Oil in originally subcommercial deposits and in drilled but undetected deposits that will be brought into production in the future.

\section{EXTENSIONS AND REVISIONS TO ESTIMATES OF OIL} IN PLACE IN KNOWN POOLS

The principal additions to reserves, as estimated yearly by the American Petroleum
Institute (API), consist of extensions and revisions of the estimated reserves of pools discovered in previous years. Sixty-three percent of these quantities over the past 15 years have resulted from extensions. Some idea of the magnitude of extensions and revisions, as compared with older reserve estimates, may be had from figure 2 . This shows that by 1960 extensions and revisions applicable to fields discovered through 1934 and 1936, respectively, had already reached a total about twice as great as the reserve estimates-made at the end of those years. Doubtless, decades will pass before the magnitude of post- 1960 extensions and revisions to estimates of pre-1960 discoveries is known fully, but the historical record suggests that they should be twice as great as the API reserve estimate at the end of 1959. Therefore, post-1960 extensions and revisions should eventually reach 64 billion barrels. Again, judging from the past, extensions alone should account for about 63 percent of this total, or about 40 billion barrels. All the reserve figures just discussed refer to producible oil, which at present is only about one-third of the oil in place. It is assumed that the average recovery will increase in the future to a level of 40 percent in those pools already discovered even if recovery is restricted to currently proved techniques. This means that the 40 billion barrels of recoverable oil in post-1960 extensions would represent about 100 billion barrels of oil in place.

\section{EFFECT OF REENTERING OLD WELLS AND NEW POOL} DISCOVERIES IN DEVELOPMENT DRILLING

The past record indicates that a number of fields and pools would be discovered even if there were no further exploratory drilling. Some of these will be found in the course of development drilling of pre-1960 discoveries; others will be found by reentering and retesting oldwells previously abandoned as dry holes or as subcommercial wells. To illustrate, the data in table 1 were compiled from the statistics on exploratory drilling as summarized in the Bulletin of the American Association of Petroleum Geologists.

No way is known to the writer of estimating, on the basis of presently available data, the quantity that will be discovered in the future by retesting pre-1960 wells and by development drilling of pre-1960 discoveries, but certainly there will be such discoveries. 


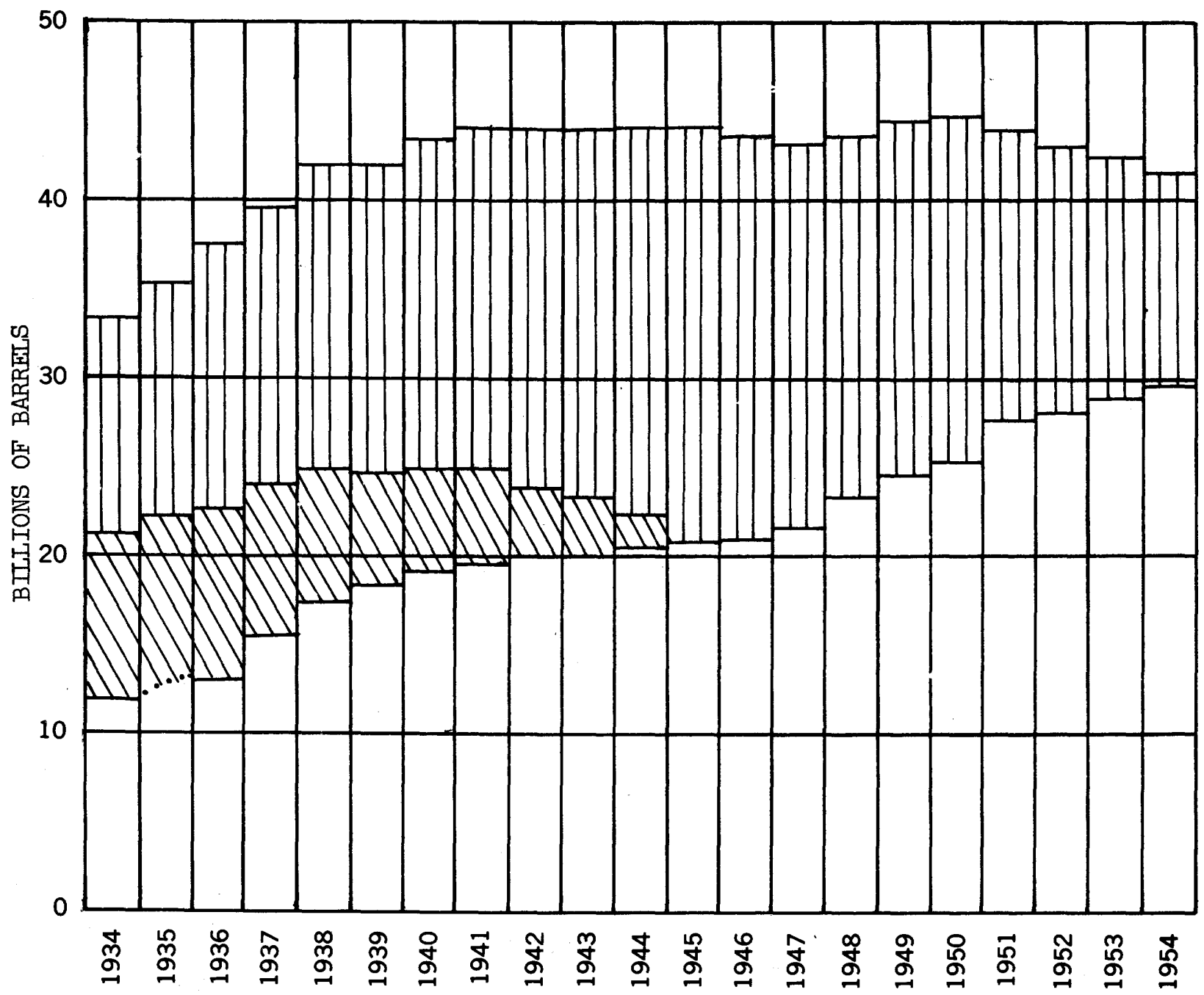

Figure 2. -Effect of crediting extensions and revisions back to year of discovery. Lower, unshaded bars are American Petroleum Institute yearly estimates of proved reserves of crude oil in the United States at the end of each year. Diagonally ruled bars are the quantities added by crediting extensions and revisions, as known in 1945, back to years of discovery. (Adapted from Buckley, 1951, chart 1, p. 21.)

Vertically ruled bars at top are the quantities similarly added by crediting back further extensions and revisions as known in 1960 . (Adapted from National Petroleum Council, 1961, table 1, by subtracting cumulative production from cumulative discoveries for each year.)

Table 1.-New fields and new pools discovered without additional exploratory drilling

Number of new fields or new pools discovered, oil and (or) gas

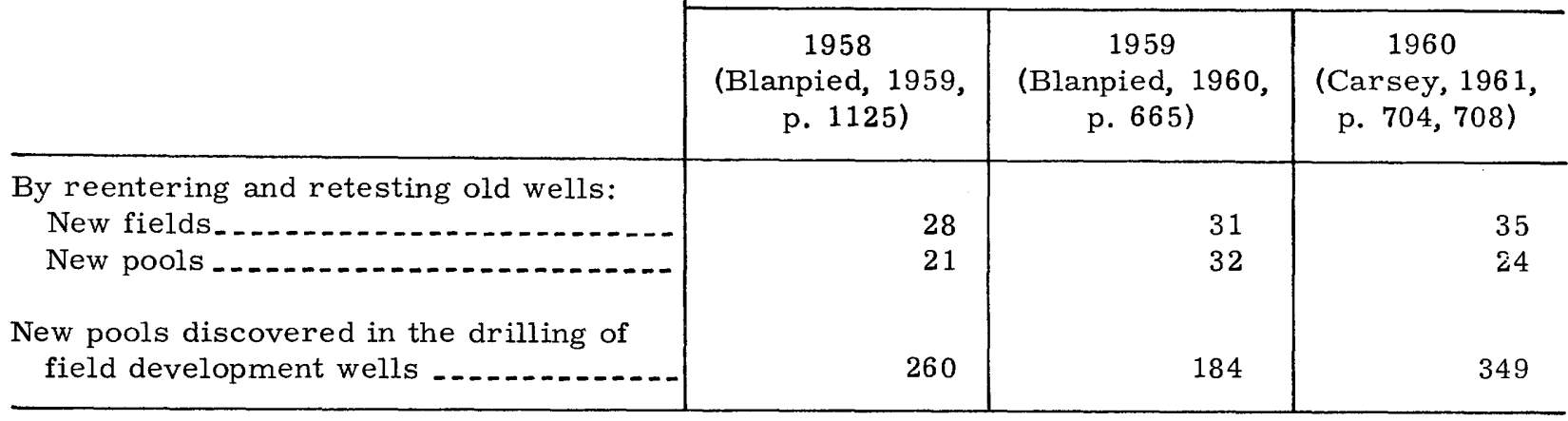


To summarize, the oil originally in place in known pools as of January 1, 1960, has been estimated at 328.4 billion barrels. Although some additional quantities of oil that will be developed within and near tested acreage cannot be estimated, the most important quantity - that from extensions of pre-1960 discoveries-presumably will reach 100 billion barrels of oil in place eventually. The total oil originally in place in explored acreage is probably between 400 and 450 billion barrels. Because of the tenuous nature of this estimate, the lower figure of 400 billion barrels is used in further discussion in this report.

\section{FUTURE DISCOVERIES OF CRUDE OIL IN THE UNITED} STATES

The exact location and extent of the undiscovered occurrences of oil and gas can be determined only by drilling. The total footage already drilled in exploratory wells, compared with the total footage of such drilling that would be required to find all the important pools, is perhaps the best measure of the fraction of the potentially productive rocks that has been explored so far.

Estimation of the total exploratory footage that would be required for complete exploration involves estimates of (1) the total volume of geologically favorable rocks and (2) the average exploratory well density that would be required.

The National Petroleum Council (1952, p. $54)$, in a summary of a symposium conducted by the American Association of Petroleum Geologists, placed the area of the United States and adjacent continental shelves that has favorable prospects for the discovery of oil and gas at 1,860,000 square miles. Since that estimate was made, the addition of Alas$\mathrm{ka}$ to the Union increased the total to slightly more than 2 million square miles.

The thickness of rocks favorable for the occurrence of oil and gas ranges generally from 1,000 feet to 40,000 feet, but the average thickness has not been determined. However, in only one basin (southern Louisiana) has a well been completed below 20,000 feet as an oil well (Oil and Gas Journal, Jan. 27, 1964 , v. 62 , no. 4 , p. 151). In the 11 basins where production has been found below 15,000 feet, 9 of the deepest wells have been completed as gas wells and only 2 as oil wells.
Most basins containing rocks favorable for occurrence of oil and gas increase progressively and gradually in depth from their margins to the deepest part. These factors indicate that an average thickness of 7,000 feet for rocks favorable for the occurrence of oil and gas is reasonable. As drilling has not reached the maximum depth of many basins, this figure seems consistent with the average depth of new field exploratory wells in the past which has increased from 4,415 feet in 1945 to 5,108 feet in 1963 (Newfarmer and Dillon, 1964, p. 769).

Economic factors doubtless will determine the density of exploratory wells that will be drilled through the section of rocks favorable for the occurrence of oil and gas. Opinions as to what density would constitute reasonably full exploration are likely to vary considerably, but the following facts are pertinent:

1. The median areal extent of pools discovered thus far in the United States is considerably less than 1 square mile.

2. Although the large pools have accounted for most past production and current reserves, important pools need not be of great areal extent. The Oil and Gas Journal (Jan. 26,1959 , v. 57, no. 4, p. 141-147) listed the most productive fields in the United States in 1958. More than 22 percent of these had an areal extent of less than 2 square miles; many less than 1 square mile.

3. Some productive areas in the United States already have an exploratory-well density greater than one well per 2 square miles, though generally the full sedimentary column has not been penetrated. A good modern example is an 8,906 square mile area in the Denver-Julesburg basin of Colorado and Nebraska that was the subject of a recent statistical study by Arps and Roberts (1958). This study included data to January 1,1958 , at which time 3,705 exploratory holes had been drilled. Through February 1962 an additional 1,877 exploratory wells had been drilled, bringing the density to one exploratory well per 1.6 square miles. Exploration is still active in the area.

This example is notable because the average productivity of the pools found is small. In the far more prolific Los Angeles Basin of California, exploratory-well density has 
reached 2 wells per square mile, with the shallower parts having a density of more than 11 wells per square mile (Barbat, 1958, p.76), and new pools are still being discovered (Doell, 1964, p. 1004-1005).

4. The presence of a dry exploratory hole does not mean that a commercial pool is not present in the immediate vicinity in the rocks penetrated. Many times development drilling has shown pools to extend to within a few hundred feet of a preexisting "dry hole" that penetrated the productive horizon.

In view of the foregoing, it is difficult to see how an average exploratory-well density of less than one well per 2 square miles could be considered total exploration, and that density is assumed here. To explore the entire body of favorable sedimentary rock to this average density would require, then, more than 7 billion feet of exploratory drilling.

Total exploratory footage drilled in the United States through 1958 has been estimated at 980 million feet (Zapp, 1962, p. H23). Exploratory drilling during 1959 raised this total to just over 1 billion feet by January 1 , 1960. Thus, the amount of unexplored favorable rocks is about six times as great as the amount already explored.

It should be emphasized that this estimate of the relative quantity of unexplored rock is $r$ ather conservative. The average thickness of the favorable rocks probably exceeds 7,000 feet, and average exploratory-well density of one well per 2 square miles would not be adequate to find even all the important pools. The device of using exploratory-drilling footage as a measure of extent of exploration does not make full allowance for the fact that the unexplored rocks are deeper, on the average, than the rocks already explored. Just how to allow for this factor is difficult to judge. Much exploration of deeper rocks is done by reentering old wells and deepening them; in such explorations no allowance need be made for the greater depth of the unexplored rocks. It was concluded that the simplest way to make allowance for this factor is through conservatism in estimating the relative quantity of unexplored rocks, as has been done above.

In the foregoing sections it was concluded that the unexplored part of the favorable rocks is at least six times greater than the explored part and that the explored part originally contained at least 400 billion barrels of crude oil. However, much of the most productive part of the favorable rocks has been drilled. That this factor is already significant is suggested by a tabulation of cumulative past production and proved reserves as compared with the cumulative exploratory footage drilled (table 2 and fig. 4), which shows that the cumulative total of past production and proved reserves per million feet of exploratory drilling decreased from the decade of 1950-60 through the 1960-63 period, but increased in 1964 to a figure slightly better than the average in the 1950's. This does not take into account that much of the addition to proved reserves in any one year or several years is from development drilling and secondary recovery improvements in exploratory discoveries in previous years, but it does suggest a definite decrease in the incidence of discoveries. In consideration of this factor, the incidence of crude oil in the unexplored rocks is assumed to range uniformly from an incidence equal to the average in the explored rocks for the richest unexplored fraction to nil for the poorest fraction. The average incidence, therefore, would be only one-half that of the explored part and the estimate of crude oil originally in place in both explored and unexplored rocks would be $400+\frac{400 \times 6}{2}$ or 1,600 billion barrels.

The foregoing assumption regarding incidence of crude oil in unexplored rock seems to be the most conservative possible without becoming unreasonable. Time after time in the past, newly explored favorable rocks have proved to be more productive than predicted, and this probably will continue to be true in the future. A considerable part of the unexplored favorable rock lies on the Continental Shelf contiguous to prolific producing areas and where major discoveries have already been made with little exploration. The Continental Shelf off the coasts of Louisiana and California appears to be particularly promising. Recent discoveries in Alaska suggest that this large area may have considerable favorable acreage. Much acreage is held by shallow or minor production in areas where prolific production has been developed in deeper rocks on acreage nearby. In addition, much favorable land is owned by oil companies in fee simple and has been withheld from exploration to date. All the factors 
Table 2.-Cumulative totals of past production, proved reserves, and exploratory footage drilled [Figures are as of Jan. 1 for year indicated]

\begin{tabular}{r|r|r|r|r}
\hline & $\begin{array}{c}(1) \\
\text { Proved reserves } \\
(1,000 \mathrm{bbl})\end{array}$ & $\begin{array}{c}(2) \\
\text { Past production } \\
(1,000 \mathrm{bbl})\end{array}$ & $\begin{array}{c}\text { (1) }+(2) \\
1 \text { million } \\
\text { barrels }\end{array}$ & \multicolumn{1}{c}{$\begin{array}{c}\text { Exploratory } \\
\text { footage } \\
\text { drilled }\end{array}$} \\
\hline 1945 & $19,941,846$ & $31,691,904$ & 51,634 & $308,701,735$ \\
1950 & $25,268,398$ & $41,033,721$ & 66,302 & $465,007,387$ \\
1955 & $30,012,170$ & $52,493,082$ & 82,505 & $759,423,088$ \\
1960. & $31,613,211$ & $64,931,492$ & 96,544 & $1,033,110,606$ \\
1965 & $30,969,990$ & $72,587,286$ & 103,557 & $1,244,654,083$ \\
\hline
\end{tabular}

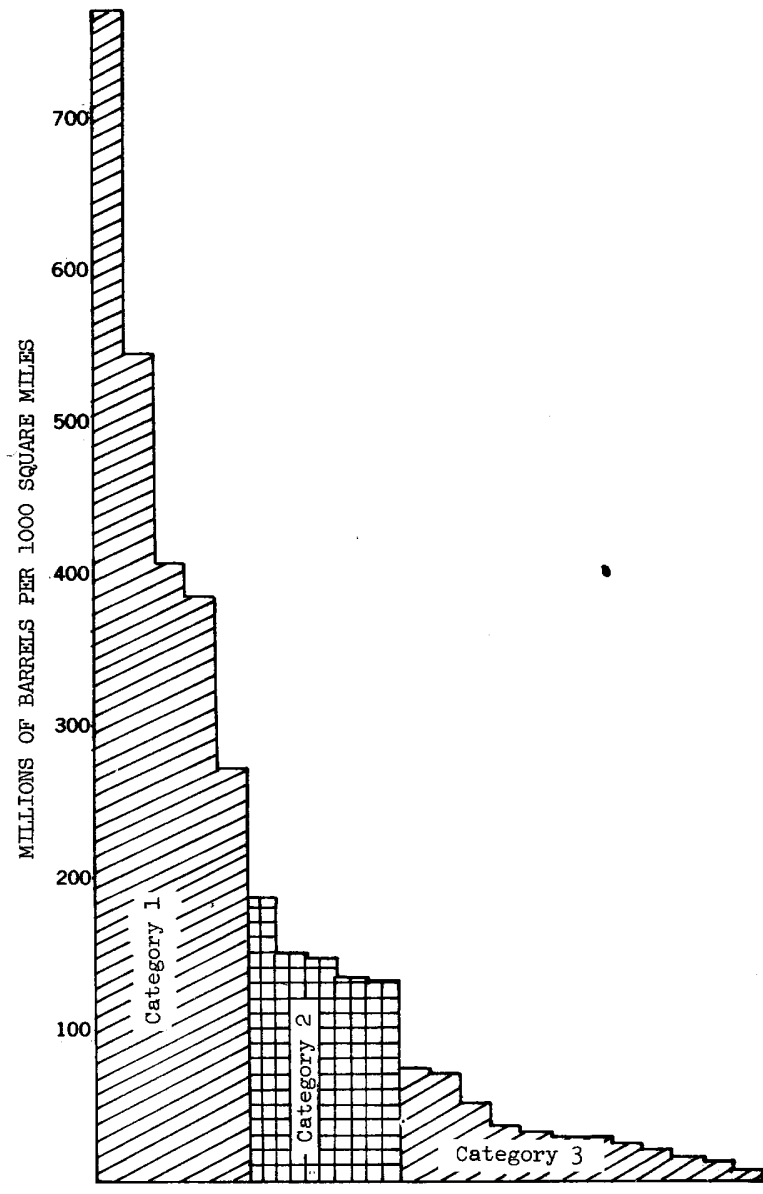

INDIVIDUAL STATES

Figure 3.-Production and proved reserves of crude oil and its equivalent by States and the grouping of States in categories of of productiveness.

indicate that much favorable acreage has yet to be explored.

\section{ECONOMICALLY PRODUCIBLE AND SUBMARGINAL} CRUDE OIL

To calculate how much of the estimated increase of 1,200 billion barrels of oil in place will prove to be economically producible, it is necessary to estimate further (1) what fraction can be found profitably and (2) what average percentage of the oil in place in discovered pools can be produced ultimately at a profit.

In view of the general trend shown in table 2 and figure 4 of an increase in the footage of exploratory drilling required to discover a unit amount of oil, it is obvious that at some stage the finding rate must decrease to a point where exploratory drilling will be unprofitable, even though geologic guidance is successful in concentrating exploration within the best of the remaining unexplored rocks. It is assumed here that economic incentive will justify exploratory drilling of at least one-third of the unexplored rocks; that is, 2 billion feet of additional exploratory drilling. It is further assumed that sound geological and geophysical guidance will concentrate future drilling within the better half of the unexplored rocks. Under the previously stated assumption as to incidence of oil, this better half would have an average incidence three-fourths as great as the explored rocks. Consequently this additional 2 billion feet of exploratory drilling (twice as much as that done prior to 1960) should discover 600 billion barrels of crude oil in place (one and one-half times the amount already found). This would bring the total of oil in place which can reasonably be expected 
to be discovered to an estimated 1,000 billion barrels.

Constant improvements in production technology that conserve the primary energy in reservoirs and the development and use of secondary-recovery techniques are steadily increasing the percentage of oil in place that can be economically recovered. Torrey (1960, p. 42-43) estimated that a National average recovery of slightly more than 40 percent is already technologically feasible, and it is assumed here that average recovery of 40 percent will ultimately be attained economically. This would mean that 400 billion barrels of the estimated 1,000 billion barrels will be recoverable after it is found. Approximately 68 billion barrels of this had already been produced through 1961 .

Subtracting the 400-billion-barrel estimate for economically recoverable oil from the 1,600-billion-barrel estimate for total oil in place gives an estimated 1,200 billion barrels of submarginal oil, partly as residual oil in produced reservoirs and partly in undiscovered pools too costly to find (fig. 1).

The foregoing estimate of economically recoverable oil assumes that the petroleum industry can continue to explore for some time with a decreasing finding rate before reaching the limit of profitability. There are many reasons for believing this to be true; some of the more important reasons are enumerated below:

1. In the past the bulk of the industry's drilling cost has been for development wells. It has long been realized that in most pools many more development wells were drilled than were needed to produce the reservoir effectively. There has been a long-term trend toward wider spacing of development wells, and there has been an acceleration of this trend in recent years. Moreover, development of successful techniques for multiple completion of both exploratory and development wells results in lower exploration and development costs. Wells have been completed from as many as seven different reservoirs; in the past, wells were rarely completed in more than one producing zone, and separate wells were drilled to each of the producing zones. Improvements in drilling equipment and techniques are constantly reducing the constant dollar-per-foot cost of drilling. The effect of these trends is that a continually increasing footage of exploratory drilling can be done without increasing the total drilling budget.

2. Through most of the past, exploratory drilling was financed from revenues from the sale of crude oil; the natural gas that was found was largely unmarketable. In the last decade the market for natural gas and natural-gas liquids has expanded enormously, and there has been a substantial increase on the average well-head price of natural gas. Revenues from natural gas and natural-gas liquids can now support a substantial part of the cost of exploration, and the trend is likely to continue to be upward in the future.

3. Considerable economic tolerance for a lower finding rate seemingly exists already, as indicated by the record of the recent past. Since World War II the finding rate for crude oil has been such that a crude-oil producing capacity of $10,585,000$ barrels daily (National Petroleum Council, 1961, p. 4)-almost one and a half times the average production rate of about 7 million barrels daily-had been achieved by January 1, 1960. Shut-in capacity, of course, generates no income; the industiy can maintain maximum economic health only if the finding rate is adequate to maintain capacity slightly greater than the rate of production.

Other factors could be listed, but the foregoing trends alone suggest that more of the rocks in partly developed basins can be explored, even in the face of a declining fincing rate.

The ultimate average recovery factor of 40 percent assumed above is probably also very conservative. Moore (1962, p. 5) pointed out that "most estimates of the ultimate percentage recovery of crude oil originally in

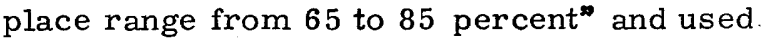
the median figure of 75 percent in his computations.

\section{UNITEC STATES RESOURCES OF NATURAL GAS AND NATURAL-GAS LIQUIDS}

Estimates of ultimate potential for natural gas and natural-gas liquids (NGL) could be derived in much the same manner as has been done above for crude oil, but the statistical record for these commodities is not nearly as complete as for crude oil. During most of the history of the petroleum industry 
in the United States, natural gas and its contained liquids found during exploration for crude oil were unwanted commodities, and ungauged large amounts were vented into the atmosphere or flared during production of associated crude oil. Discoveries of natural gas without associated crude oil, if remote from market, were left undeveloped. In the last decade or sothere has been an enormous expansion in transportation facilities and market for natural gas and its contained liquids; and very recently the production of these commodities, on an energy basis, caught up with and passed domestically produced crude oil. Deliberate exploration for natural gas is now becoming widespread, and henceforth the search for natural gas and the rate of development of gas discoveries will probably be comparable to those for crude oil. However, as of now, the statistical record of the past is much poorer for natural gas than for crude oil.

Natural gas and NGL are usually genetically associated with crude oil and commonly occur with it. Some reservoirs contain only crude oil, and some contain only gas, with or without a significant liquid hydrocarbon content. Some of the gas that occurs alone contains virtually no heavy hydrocarbons and is considered "dry" or "nonassociated" gas. However, average ratios of occurrence for a large and geologically diversified part of the earth's crust, such as the United States, are likely to be relatively uniform. To determine from statistics just what the average ratio of occurrence is, the statistics should be for a period in which effort expended in searching for and developing each commodity was comparable. As discussed above, that stage has not yet been reached but is being approached rapidly. Accordingly, recent statistics and trends should give at least a fair idea of the average ratios of occurrence of gas and NGL to oil that may be expected ultimately. Such average ratios of occurrence, applied to the estimates for crude oil, are considered to be the most realistic basis for arriving at estimates for natural gas and NGL.

The gross additions to reserves, as estimated yearly by the American Petroleum Institute and the American Gas Association, afford perhaps the best information on average ratio of occurrence of natural gas and oil. Their statistics for the period 1952-56 showed a ratio of 6,182 cubic feet of natural gas per barrel of oil; for the period 1957-62 the ratio was 6,637 cubic feet per barrel.
The rising trend results from the increasing effort toward finding and development of gas reserves; it may also result in part from the greater average depth of drilling. The ratio will doubtless continue to increase, but in this report a conservative figure of 6,667 cubic feet of natural gas per barrel of crude oil is used. The for egoing data relate to economically producible quantities; the current average recovery factor for crude oil is about 30 percent, whereas for more mobile natural gas it is about 80 percent. On the basis of the se factors, the 6,667-cubic-feetper-barrel ratio for economically recoverable quantities is equivalent to a 2,500-cubicfeet-per-barrel ratio for the commodities estimated as being originally in place.

Applying this ratio of 2,500 cubic feet per barrel to the previous 1,600-billion-barrel estimate for ultimate crude oil in place gives an estimate of 4,000 trillion cubic feet for natural gas. Applying the ratio to the 1,000billion-barrel estimate of the total crude oil that will be found ultimately indicates that 2,500 trillion cubic feet of natural gas will be found. At the 80 percent recovery factor, 2,000 trillion cubic feet would be producible. Subtracting this from the estimated total in the ground gives an estimated 2,000 trillion cubic feet for the submarginal quantity that will either not be found or cannot be produced economically if found. No increase in the average recovery factor is assumed, although greater recovery is known to be technologically feasible.

The quantity of this natural gas that has already been produced is not accurately known, for no one knows how much gas was wasted in the early years of the industry, and only estimates rather than measurements are made of more recent wastage. However, with a rough allowance for wastage, production through 1961 has probably been of the general magnitude of 230 trillion cubic feet.

Because NGL occur in the same system with natural gas, recent production figures should give a good indication of the average ratio of occurrence. The production figures of the American Gas Association for the past 10 years indicate a ratio of about 32 barrels of NGL per million cubic feet of natural gas; during the same period gross additions to reserves indicate about the same ratio. In this report, this is rounded off to 30 barrels per million cubic feet for the purpose of deriving estimates. Applying this factor to the 
foregoing estimates for natural gas yields estimates for NGL of 120 billion barrels as the total in the ground, of which 60 billion would be producible and 60 billion submarginal. More of the natural gas that is produced could be processed for NGL, and it is technologically feasible to increase the average amount recovered from the processed gas; but as no net increase in the combined heat value of natural gas and NGL would result, it seems unnecessary to estimate the amounts.

As is true for natural gas, and for the same reasons, total past production of NGL from reservoirs cannot be accurately determined, but through 1961 such production has probably totaled between 6 and 7 billion barrels.

\section{SUMMARY OF UNITED STATES RESOURCES OF CRUDE OIL, NATURAL GAS, AND NATURAL-GAS LIQUIDS}

The estimated quantities of petroleum, natural gas, and NGL originally underlying the United States and adjacent continental shelves, as derived in the preceding section of this report, are summarized in table 3 .

It should be emphasized that the quantities in the table below are minimum quantities, as conservatism was used throughout in deriving them. They are probably particularly conservative as regards natural gas and NGL, as there is a growing body of evidence that these commodities occur in greater relative quantities with increasing depth. As has been pointed out previously, most of the production thus far found at depths of more than 15,000 feet has been gas or gas condensate. All the estimates will probably be revised upward in the future when more information is available. The total future exploratory drilling estimated in this report, 2 billion feet, will be completed by the end of the current century if such drilling continues at present rates.

It should also be emphasized that underground quantities, however large, are relatively meaningless until they are found and brought into production, and this will be done only if incentive to do so is adequate. Moreover, underground quantities do not in any way reflect the rate at which the commodities can be produced. To be efficient, exploration and development must proceed slowly, making full use of each increment of knowledge from previous drilling. Furthermore, once a reservoir has been drilled, there is a definite limit to the rate at which its contained fluids can be withdrawn-generally many decades are required to exhaust a reservoir. Total resources in the ground and the amounts that ultimately will be discovered and produced are important, but for economic and political considerations in the next few decades the current capacity for production and the outlook for maintaining that capacity are of greater importance.

\section{POTENTIAL WORLD RESOURCES OF OIL, GAS, AND NATURAL-GAS LIQUIDS}

At present it is impossible to relate resources of oil, gas, and NGL of the United States to those of the world in terms of United States categories of producing, marginal and submarginal. Many areas of the world are not well known geologically, and vast areas have not been explored by drilling. Many potential producing areas of the world are remote from markets and difficult

Table 3.-Oil, gas, and natural-gas liquids originally underlying the United States

\begin{tabular}{|c|c|c|c|c|}
\hline & $\begin{array}{l}1 \\
\text { Crude oil } \\
\text { (billions } \\
\text { of } \\
\text { ba:rels) }\end{array}$ & $\begin{array}{l}2 \\
\text { Natural } \\
\text { gas } \\
\text { (trillions } \\
\text { of cu } \\
\text { ft) }\end{array}$ & $\begin{array}{l}3 \\
\text { NGL } \\
\text { (billions } \\
\text { of } \\
\text { barrels) }\end{array}$ & $\begin{array}{c}4 \\
\text { Total liquid } \\
\text { hydrocarbons } \\
(1+3) \\
\text { (billions of } \\
\text { barrels) }\end{array}$ \\
\hline $\begin{array}{l}\text { Total in place } \\
\text { Total in place to be found by exploration } \\
\text { Economically recoverable } \\
\text { Submarginal } \\
\text { Approximate production through } 1961 \text {, for } \\
\text { comparison. }\end{array}$ & $\begin{array}{r}1,600 \\
1,000 \\
400 \\
1,200 \\
68\end{array}$ & $\begin{array}{r}4,000 \\
2,500 \\
2,000 \\
2,000 \\
\\
230\end{array}$ & $\begin{array}{r}120 \\
75 \\
60 \\
60 \\
6-7\end{array}$ & $\begin{array}{r}1,720 \\
1,075 \\
460 \\
1,260 \\
74-75\end{array}$ \\
\hline
\end{tabular}


of excess to the facilities required for exploration and production. The economic setting and absence of geological and well data do not permit the determination of marginal and submarginal categories. However, the amount of oil, natural gas, and NGL originally in place in the world can, be estimated by comparing by area the relative attractiveness for hydrocarbon abundance of the sedimentary basins of the remainder of the world with similar basins in the United States.

\section{COMPARISON OF THE RELATIVELY HIGHLY EXPLORED AREAS OF THE UNITED STATES WITH THE REMAINDER OF THE WORLD}

No completely satisfactory method cain be used to establish categories of the relative incidence of deposits of oil, gas, and NGL in the various provinces of the United States. If data were available, the amount of each in place might be related to the volume of sedimentary rock by provinces. If more detailed data were available, the amounts might be further related to rock types on the basis of an arbitrarily assumed or statistically derived relative incidence of deposits of oil, gas, and NGL in each rock type.

\section{RELATIVE PRODUCTIVITY OF VARIOUS AREAS IN THE} UNITED STATES

A method of classifying the area of sedimentary rocks of the United States as to their productivity was arrived at by using easily obtainable figures. The figures are available by States rather than by geologic or petroliferous provinces, which wouid have been preferable. The method is described below:

1. Past production of crude oil and natural gas to January 1,1962 , was added to proved reserves as of January 1, 1962, by States.

2. The amount of NGL produced and wasted was computed on the basis of 1 barrel for each 20,000 cubic feet of gas produced except for areas of dry gas where the factor was arbitrarily reduced by approximately half, which brings the average approximately to 30 barrels per million cubic feet assumed for the United States as a whole. Reserves of NGL were related to reserves of gas on the same basis. The resulting figures were checked for general validity against the rate of production of NGL as compared with those of natural gas in recent yea'rs.
3. Natural gas was converted to crude-oil equivalent by considering each 5.6 MCF equivalent to a barrel of oil.

4. Crude oil and NGL past production and reserves were combined for each State and the natural gas equivalent was added thereto,

5. The area of sedimentary basins in which oil and gas has been found was outlined and measured by planimetry.

6. The combined past production and proved reserves in millions of barrels was divided by the area in units of 1,000 square miles for each State.

7. The State factors of millions of barrels per thousand square miles of productive area were tabulated in decreasing order. Fairly sharp breaks occurred at two points and served to group States into three classes of productivity (table 4, col. 1, and fig. 3).

8. For each of the three classes, production and proved reserves for all States in the class were combined for crude oil, for natural gas, and for NGL.

9. The total production and reserve figure for each commodity in all States in each class was divided by the combined productive area in States in each class to obtain a figure of production and reserves per thousand square miles (table 4, col. 2).

10. One-sixteenth of the total resources of crude oil, natural gas, and NGL was arbitrarily assigned to currently nonproductive areas of sedimentary rocks which was estimated as 1 million square miles.

11. Past production and reserves of each commodity were totaled, and the percentage of the total in each class was determined.

12. Past production and the proving of reserves were assumed to have been in direct ratio to the amount of each commodity originally in place. Therefore the total resource figure for each commodity in the United States was multiplied by factors thus derived for areas of each class to obtain a total resource figure for the area in the United States in each class.

13. The total resource figure was divided by the area in the United States in each class separately for crude oil, natural gas, and NGL 


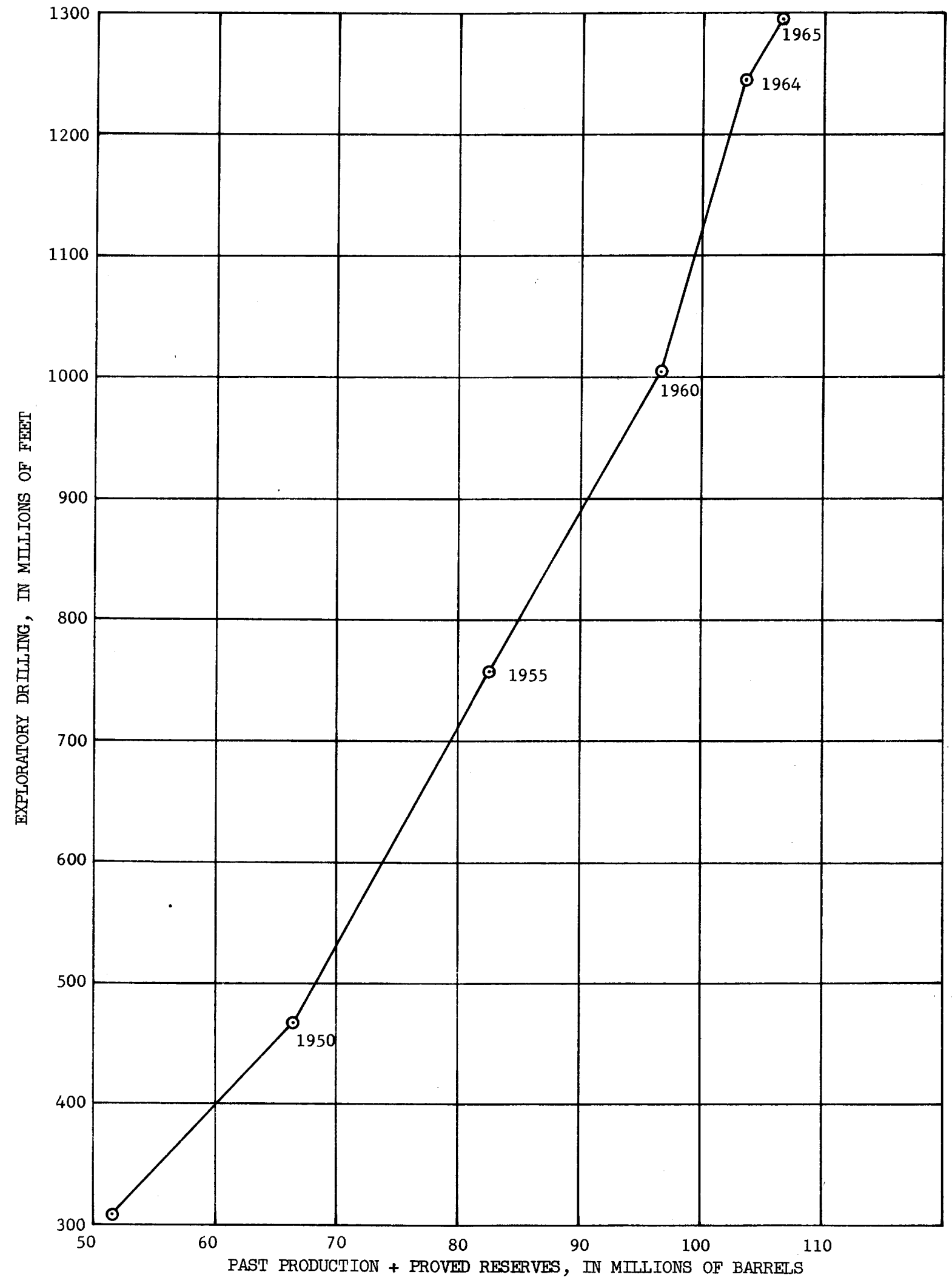

Figure 4.-Cumulative totals of past production plus proved reserves as compared with cumulative total of exploratory footage drilled. 
Table 4.-Production and proved reserves of crude oil, natural-gas equivalent, and natural-gas liquids by States as of January 1, 1962

\begin{tabular}{|c|c|c|c|c|}
\hline \multirow[t]{2}{*}{ State } & \multirow[t]{2}{*}{$\begin{array}{l}\text { Production and } \\
\text { proved reserves } \\
\text { (millions of } \\
\text { barrels) }\end{array}$} & \multirow[t]{2}{*}{$\begin{array}{c}\text { Unit of } \\
1,000 \text { square } \\
\text { miles of } \\
\text { productive } \\
\text { area }\end{array}$} & $\begin{array}{l}\text { Production and } \\
\text { proved reserves } \\
\text { (millions of } \\
\text { barrels per } \\
1,000 \mathrm{sq} \mathrm{mi} \text { ) }\end{array}$ & $\begin{array}{c}\text { Average by categories } \\
\text { of favorableness }\end{array}$ \\
\hline & & & 1 & 2 \\
\hline California_._...... & 21,554 & 28 & 770 & \\
\hline Louisiana _....... & 31,543 & 58 & 544 & \\
\hline Texas _......... & 83,585 & 207 & 404 & 430 (161,988 million barrels, \\
\hline New Mexico ...... & 7,686 & 20 & 384 & \\
\hline Oklahoma ........ & 17,620 & 64 & 272 & \\
\hline Arkansas _........ & 1,868 & 10 & 187 & \\
\hline Pennsylvania ...... & 2,717 & 18 & 150 & $146(20.609$ million barrels. \\
\hline Kansas . . . . . & 10,055 & 68 & 148 & area $141,000 \mathrm{sq} \mathrm{mi}$. \\
\hline Illinois . . & 2,928 & 22 & 133 & \\
\hline West Virginia .... & 3,041 & 23 & 132 & \\
\hline Wyoming......... & 4,848 & 65 & 75 & \\
\hline Mississippi & 2,196 & 31 & 71 & \\
\hline Nebraska _........ & 310 & 6 & 52 & \\
\hline Utah. & 843 & 22 & 38 & \\
\hline Kentucky_........ & 1,236 & 37 & 33 & \\
\hline Colorado_... & 1,663 & 56 & 30 & $32(16,863$ million barrels, \\
\hline Miscellaneous _... & 1,857 & 61 & 30 & area $530,000 \mathrm{sq} \mathrm{mi})$ \\
\hline Ohio............ & 1,089 & 42 & 26 & \\
\hline Michigan__._....- & 725 & 35 & 21 & \\
\hline North Dakota _...-- & 836 & 54 & 16 & \\
\hline Indiana $\ldots \ldots$ & 414 & 29 & 14 & \\
\hline Montana $\ldots \ldots$ & 846 & 92 & 9 & \\
\hline
\end{tabular}

Table 5.-Amount of oil, natural gas, and natural-gas liquids in areas of various degrees of potential in the United States

\begin{tabular}{|c|c|c|c|c|c|}
\hline & \multicolumn{5}{|c|}{ Category } \\
\hline & 1 & 2 & 3 & 4 & 5 \\
\hline Crude oil-million barrels per $1,000 \mathrm{sq} \mathrm{mi}$ & 3,000 & 1,000 & 250 & 100 & \\
\hline Natural gas-trillion cubic feet per $1,000 \mathrm{sq}$ mi... & & 3 & & .25 & 0.025 \\
\hline NGL-million barrels per $1,000 \mathrm{sq} \mathrm{mi}$ & 250 & 80 & 20 & 10 & ........ \\
\hline
\end{tabular}

to dete:-mine a figure for total resources per thousand square miles for each commodity in each class.

The four categories so established for each of the three commodities estimated as being originally in place were rounded off as shown in table 5. Category 5 was added to account for areas yielding only dry unassociated gas.

APPLICATION OF FACTORS DERIVED FOR THE UNITED STATES TO THE REMAINDER OF THE WORLD

The categories were applied to the sedimentary basins and areas of the world as judged by a comparison with those of the United States. It is realized that no two geologists could be expected to agree on the classification of all areas, but it is probable that the differences average out when large regions are considered. As a first step, a broad survey was made, country by country, of the geologic literature of the world, to determine the location and extent of sedimentary basins and areas, the results of drilled wells, and past and present production and reserves if known or estimated. Next the sedimentary areas were plotted on a world map, together with known pools of oil and 
gas, and then divided into four categories that were judged to be similar in prospective production per 1,000 square miles to those determined for the United States. A fifth category was added to cover possible incidence of natural gas in sedimentary rocks at least 1,000 feet thick but considered unfavorable for occurrence of oil. For this category an estimate of 0.25 trillion cubic feet of natural gas per 1,000 square miles was arbitrarily assumed. Each land area in a particular category was planimetered, and the number of square miles was determined, which was then multiplied by the factors that were derived for the United States for oil, gas, and NGL for that category. The totals of all categories for each commodity were then combined for a continent or other geologically related area.

The continental shelves bordering sedimentary areas or basin margins on land were also outlined to a water depth of 600 feet on the world map. They were assigned categories similar to those of the bordering coast (or lower if considered less favorable then the coast), and their area was determined by planimetry. The total amounts of oil, gas, and NGL in place were then estimated for the shelves by the same method as for the land areas. The categories assigned the shelf are at many places undoubtedly conservative. Only those shelves bordering sedimentary areas were evaluated, whereas many shelves that border areas of igneous or metamorphic rocks may consist largely of detrital sediments of great thickness that contain organic material and interfinger with marine sediments. Some of these sediments may contain accumulations of oil or gas. Furthermore, many areas in water deeper than 600 feet probably will be productive ultimately.

The combined totals for the land and shelf areas as shown in table 6 are believed to give reasonable estimates of total oil, gas, and NGL originally in place as compared to estimates of these totals for the United States. Figures for individual areas may be too low or too high, but overall the figures are believed to be of the right order of magnitude. The possible future projected drilling in the United States is based on the total exploratory footage drilled and the necessary additional footage required to bring the incidence of exploration to the density of one well per 2 square miles assumed as reason- able to test adequately the total sedimentary rocks of the United States. This would require at least six times as much footage as has been drilled in the past. These assumptions of future requirements for total exploration in the United States to test adequately the known sediments, as well as the projected incidence of oil, natural gas, and NGL based thereon, have been extrapolated throughout the world's sedimentary areas. The resulting figures of commodity incidence for many untested world areas may be extremely conservative, however, because of relatively low favorability assumed where geologic information is lacking or sparse. In other areas where drilling has been at a low rate-for example one well per several thousand square miles-without finding commercial accumulations, a category may have been assigned that future exploration may show is far too conservative.

The estimate of the world resources of natural gas "originally in place" may seem astronomical, but the categories as determined attribute only very small amounts of gas to large areas in the world that may contain only nonassociated natural gas. Many sedimentary areas are more favorable for occurrence of natural gas than for oil. In the past the discoveries of gas have largely been incidental to the search for oil, and intensive exploration has been confined mainly to those sedimentary areas with more obvious structural features and the best prospect for oil. Large stratigraphic traps, for which little search has been made so far, are more likely to contain gas or mixed fluids than oil. In the future, vast areas of sediments that were considered unfavorable for oil or that have not been explored will be prospected for natural gas-for example, sediments of continental origin similar to those of the Kenai Formation in Alaska, or those of recent age as in the gas field of Pleistocene age in the St. Lawrence valley of Quebec, or in wells of great depth where the ratio of gas and gas condensate to oil rises, as in the Gulf Coast of the United States where the ratio rises from 54 percent at depths of more than 8,000 feet to 70 percent at depths of more than 12,000 feet.

How much of the natural gas that was originally in place will be recovered will depend largely on the economic needs, both industrial and domestic, of the region in which they are discovered and on new developments 
Table 6.-Estimated quantities of petroleum and natural gas originally in place in world areas and bordering continental shelves

\begin{tabular}{|c|c|c|c|c|c|c|}
\hline \multirow[b]{2}{*}{ r } & \multicolumn{2}{|c|}{$\begin{array}{c}\text { Crude oil } \\
\text { (b illions of barrels) }\end{array}$} & \multicolumn{2}{|c|}{$\begin{array}{c}\text { Natural gas } \\
\text { (trillions of cubic feet) }\end{array}$} & \multicolumn{2}{|c|}{$\begin{array}{c}\text { NGL } \\
\text { (billions of barrels) }\end{array}$} \\
\hline & 1 & $1_{2}$ & 1 & 22 & 1 & ${ }^{3} 2$ \\
\hline \multirow{8}{*}{$\begin{array}{l}\text { Canada, Mexico, Central } \\
\text { America, and Caribbean } \\
\text { South America } \\
\text { Europe. } \\
\text { Africa } \\
\text { Middle East } \\
\text { South Asia, } \\
\text { USSR, China, and Mongolia } \\
\text { Australia, East Indies, and } \\
\quad \text { Pacific Islands. }\end{array}$} & 500 & 300 & 3,500 & 2,200 & 40 & 25 \\
\hline & 800 & 500 & 2,500 & 1,600 & 70 & 45 \\
\hline & 500 & 300 & 1,300 & 800 & 40 & 25 \\
\hline & 1,800 & 1,100 & 5,400 & 3,400 & 150 & 95 \\
\hline & 1,400 & 900 & 3,600 & 2,200 & 120 & 75 \\
\hline & 200 & 100 & 600 & 400 & 20 & 10 \\
\hline & 2,900 & 1,800 & 8,500 & 5,300 & 240 & 150 \\
\hline & 300 & 200 & 1,100 & 700 & 30 & 20 \\
\hline \multirow{2}{*}{$\begin{array}{l}\text { Total: } \\
\text { World excluding United } \\
\quad \text { States... }\end{array}$} & & & & & & \\
\hline & 8,400 & 5,200 & 26,500 & 16,600 & 710 & 445 \\
\hline United States & 1,600 & 1,000 & 4,000 & 2,500 & 120 & 75 \\
\hline World & 10,000 & 6,200 & 30,500 & 19,100 & 830 & 520 \\
\hline
\end{tabular}

${ }^{1}$ Figures rounded off to the nearest 50 billion barrels.

${ }^{2}$ Figures rounded off to the nearest 100 trillion $\mathrm{cu} \mathrm{ft}$.

${ }^{3}$ Figures rounded off to the nearest 5 billion barrels.

1. Total in place.

2. Possible ultimate discoveries. How much might be economically recoverable is dependent upon many factors related to the geologic occurrence, geographic accessibility, and economic developments and would be variable between the United States and other countries as well as between countries. In many places outside the United States, the economically recoverable part of the possible ultimate discoveries may exceed the conservative percentage assumed in this paper for the several commodities as economically recoverable in the United States.

in methods of transportation. Gas is becoming of increasing importance in the world's economy. In the past the search for it was confined largely to those areas that lay relatively close to large industrial and domestic outlets or close to existing pipelines. The increased demand within the North American continent is being met by the discovery and development of vast new deposits, particularly in western Canada. For Europe the fuel requirements of an increasing industrial development are being met increasingly by the discoveries of new gas reserves in the Netherlands, France, and beneath the North Sea. In the future, gas from the large fields in North Africa will likely be transported to Europe. The discoveries of natural gas in North Africa and their possible uses there and abroad are only in the early stages of prospecting and development.

Weeks (1963) and Torrey, Moore, and Weber (1963) estimated the reserves of discovered reserves of crude oil in the world by various categories. These estimates and ratios based on them are given in table 7 together with estimates of total oil originally in the ground and the amount expected to be discovered. 
Table 7. - World oil resources by regions

[The basic unit used is barrels of 42 U.S. gallons. Columns 1 through 6 are in billions of barrels, and columns 1 and 2 are rounded off to the closest 50 billion. Columns 7 through 9 are in millions of barrels because the amounts can be computed accurately]

\begin{tabular}{|c|c|c|c|c|c|c|c|c|c|c|c|c|}
\hline & $1_{1}$ & ${ }^{1} 2$ & ${ }^{2} 3$ & 24 & $2_{5}$ & ${ }^{2} 6$ & ${ }^{3} 7$ & ${ }^{2} 8$ & ${ }^{2} 9$ & 10 & 11 & 12 \\
\hline United States_. & 1,600 & 1,000 & 346 & 31 & 16 & 47 & 37,000 & 2,511 & 67,657 & 31.2 & 21 & 9 \\
\hline $\begin{array}{l}\text { Canada, Mexico, Central } \\
\text { America, and Carib- } \\
\text { bean }\end{array}$ & 500 & 300 & 50 & 8 & 2 & 10 & 8,300 & 374 & 5,945 & 4.7 & 30 & 19 \\
\hline South America & 800 & 500 & 214 & 21 & 7 & 28 & 22,937 & 1,273 & 17,703 & 15.8 & 8 & 11 \\
\hline $\begin{array}{l}\text { Total Western Hemi- } \\
\text { sphere }\end{array}$ & 2,900 & 1,800 & 610 & 60 & 25 & 85 & 68,237 & 4,158 & 91,305 & 51.7 & 21 & 10 \\
\hline Europe & 500 & 300 & 21 & 3 & 1 & 4 & 3,111 & 224 & 3,487 & 2.8 & 75 & 43 \\
\hline Africa & 1,800 & 1,100 & 56 & 10 & & 10 & 12,125 & 180 & 618 & 2.2 & 110 & 69 \\
\hline Middle East_. & 1,400 & 900 & 794 & 190 & 97 & 287 & 208,870 & 2,060 & 18,328 & 25.6 & 3 & 3 \\
\hline South Asia & 200 & 100 & 3 & 1 & 0 & 1 & 575 & 10 & 421 & .1 & 100 & 100 \\
\hline USSR, China, and & & & & & & & & & & & & \\
\hline Mongolia & 2,900 & 1,800 & 89 & 25 & 8 & 33 & 33,500 & 1,225 & 14,106 & 15.2 & 55 & 38 \\
\hline $\begin{array}{l}\text { Indonesia, Australia, and } \\
\text { Pacific Islands }\end{array}$ & 300 & 200 & 27 & 9 & 0 & 9 & 11,800 & 194 & 3,122 & 2.4 & 22 & 17 \\
\hline $\begin{array}{l}\text { Total Eastern Hemi- } \\
\text { sphere }\end{array}$ & 7,100 & 4,400 & 990 & 238 & 106 & 344 & 269,981 & 3,893 & 40,082 & 48.3 & 13 & 11 \\
\hline Total world & 10,000 & 6,200 & 1,600 & 298 & 131 & 429 & 338,218 & 8,051 & 131,387 & 100.0 & 15 & 12 \\
\hline
\end{tabular}

1 Figures rounded off to the nearest 50 billion barrels.

${ }^{2}$ Figures after Torrey, Moore, and Weber (1963).

${ }^{3}$ Figures after Weeks (1963).

1. Total oil estimated to be in the ground.

2. Amount of oil that can be expected to be discovered.

3. Estimate of original oil content of known reservoirs.

4. Estimate of primary oil reserves.

5. Additional oil reserves from conventional fluid injection operations.

6. Combined primary + fluid injection reserves (col. $4+$ col. 5).

7. Reserves producible by methods now in operation.

8. Oil production in 1961.

9. Total cumulative oil production to Jan. $1,1962$.

10. Percentage of 1961 oil production by regions.

11. Ratio of oil to be discovered to cumulative reserves (col. $2 / \mathrm{col} .6$ ).

12. Ratio of oil to be discovered to past production + cumulative reserves (col. $2 / \operatorname{col} .6+9)$.

\section{CONCLUSION}

Crude oil originally in place in the world is considered to be of the order of magnitude of 10,000 billion barrels; about 6,000 billion barrels may be expected to be discovered. Natural gas originally in place is of the order of magnitude of 30,000 trillion cubic feet, of which about 20,000 trillion may be discovered and with which will be associated more than 800 billion barrels of NGL of which about 500 billion barrels may be associated with the gas to be discovered. Table 6 summarizes the estimates for the world derived by the method described in the foregoing text.

The data, estimates, and computations in table 7 indicate clearly that the United States, the Middle East, South America (principally Venezuela), and the USSR will dominate production until 1970. The large proved reserves 
of the Middle East indicate that the importance of that region is certain to grow signifcantly at least until 1975. The large potential for additional discovery of oil in favorable but unexplored areas in Africa and the USSR suggests that the impact of those regions on oil economics will grow greatly by 1980 .

It is realized that the data available only permit estimates of world resources of oil, gas, and NGL of gross accuracy to be made. Individual elements used in preparing the estimates unquestionably contain errors. However, the method of considering elements of computation in extremely comprehensive units tends to average out individual discrepancies, and the consistent selection of the most conservative of possible alternatives provides a reasonable insurance that the estimates are of a magnitude that can be attained.

Much of the undiscovered and undeveloped resources of crude oil, natural gas, and NGL are in the deep parts of partly explored basins, beneath the waters of the Continental Shelf, in remote areas of Alaska, and in foreign countries. In such areas exploration, development, production, and transportation costs are high, and large-scale operation is essential for successful operation. An increasing amount of oil produced is associated with natural gas and NGL, a fact that greatly complicates marketing.

The potential world supply of oil, gas, and NGL in place in the ground is large, the major part of the supply can be discovered, and a large part of that discovered can be produced when economic and political factors warrant the effort and other expenditures necessary to win it.

\section{REFERENCES}

American Petroleum Institute and American Gas Institute, 1945, 1950, 1955, 1960, 1963, 1964, Reports on proved reserves of crude oil, natural gas liquids, and natural gas in the United States and Canada: New York, Am. Petroleum Inst.

Arps, J. J., and Robert., T. G., 1958, Economics of drilling for Cretaceous oil on east flank of Denver-Julesburg basin: Am. Assoc. Petroleum Geologists Bull., v. 42, no. 11 , p. 2549-2566.

Barbat, W. F., 1958, The Los Angeles Basin area, California, in Weeks, L. G., ed., Habitat of oil, a symposium: Tulsa, Okla., Am. Assoc. Petroleum Geologists, p. 62-76.
Buckley, S. E., ed., 1951, Petroleum conservation: New York, Am. Inst. Mining and Metall. Engineers, 304 p.

Buckley, S. E., Hocott, C. R., and Taggard, M. S., Jr., 1958, Distribution of dissolved hydrocarbons in subsurface waters, in Weeks, L. G., ed., Habitat of oil, a symposium: Tulsa, Okla., Am. Assoc. Petroleum Geologists, p. 850-882.

Blanpied, B. W., 1959, Exploratory drilling in 1958: Am. Assoc. Petroleum Geologists Bull., v. 43, no. 6, p. 1117-1138.

1960, Exploratory drilling in 1959: Am. Assoc. Petroleum Geologists Bull., v. 44, no. 6, p. 657-682.

Carsey, J. B., 1961, Exploratory drilling in 1960: Am. Assoc. Petroleum Geologists Bull., v. 45, no. 6, p. 701-727.

Doell, E. C., 1964, Developments in west coast area in 1963: Am. Assoc. Petroleum Geologists Bull., v. 48, no. 2, p. 1004-1005.

Hubbert, M. K., 1962, Energy resources-a report to the committee on natural resources of the National Academy of Sciences-National Research Council: Nat. Acad. Sci.-Nat. Research Council Publ. 1000-D.

Lasky, S. G., and others, 1962, Report of the national fuels and energy study group on an assessment of available information on energy in the United States, U.S. Congress, Senate Committee on Interior and Insular Affairs: U.S. 87th Cong., 2d sess., p. 79.

McKelvey, V. E., and Duncan, D. C., 1963, United States resources of fossil fuels, table 1, in Supplies, costs and uses of fossil fuels: Energy Policy Staff, U.S. Dept. of the Interior, Washington, D.C.

Moore, C. L., 1962, Method for evaluating U.S. crude oil resources and projecting domestic crude oil availability: U.S. Dept. of the Interior Office of Oil and Gas.

National Petroleum Council, 1952, Petroleum productive capacity: Washington Natl. Petroleum Council, 102 p.

1961, Proved discoveries and productive capacity of crude oil, natural gas, and natural gas-liquids in the United States: Washington Natl. Petroleum Council, 40 p., 7 tables.

Netshcert, B. C., 1958, The future supply of oil and gas: Baltimore, Md., The Johns Hopkins Press, $134 \mathrm{p}$.

Newfarmer, L. R., and Dillon, E. L., 1964, Exploratory drilling in 1963: Am. Assoc. Petroleum Geologists Bull., v. 48, no. 6, p. 769.

Torrey, P. D., 1960, Evaluation of United States oil resources as of January 1, 1960: The 
Oil and Gas Compact Bull., v. 19, no. 1, p. 41-52.

Torrey, P. D., Moore, C. L., and Weber, G. H., 1963, World oil resources: Frankfurt A/ Main, preprint 6th Internat. Petroleum Cong., June 1963, p. 16-28:

Weeks, L. G., 1948, Highlights on 1947 developments in foreign petroleum fields: Am. Assoc. Petroleum Geologists Bull., v. 32, p. 1094.

1958, Fuel reserves of the future: Am. Assoc. Petroleum Geologists Bull., v. 42, p. 434 .
Weeks, L. G., 1959, Where will energy come from in 2059: The Petroleum Engineer, v. 31, August, p. A-25.

1963, Worldwide review of petroleum exploration: Frankfurt, A/Main, preprint 6th Internat. Petroleum Cong., June 1963, p. $38-41$.

Zapp, A. D., 1962, Future petroleum producing capacity in the United States: U.S. Geol. Survey Bull. 1142-H, 36 p. 